Volume: 11 Issue: 2 Year: 2014

\title{
Teachers of the future: Perceived teaching competences and visions of pre-service English language teachers
}

\author{
Hatice Gülru Yüksel ${ }^{1}$
}

\begin{abstract}
The changes observed in the early 1990s have altered the conceptions of learning and teaching in the 21 st century, which in turn have raised questions about the nature of teacher education and the core knowledge and skills to be taught to student teachers. Gaining insights about how student teachers project themselves as teachers of 21 st century and how they assess their teaching capabilities became crucial for teacher educators and policy makers. This study was conducted with 40 pre-service teachers of English as a foreign language to investigate how they assess their teaching competences and how they project themselves as teachers of future. The study employed a convergent parallel mixed-method design. The findings from quantitative data indicated that their perception related to various teaching competencies was uniform and they feel themselves competent enough in teaching. However, they needed further help in classroom management. The qualitative data can be interpreted as a signal that our participants will possibly adopt a constructivist approach to language teaching.
\end{abstract}

Keywords: English as a foreign language; Pre-service teachers; Teaching competence; Teacher education; Teacher vision

\section{Introduction}

The twenty-first century students are expected to master content while producing, synthesizing and evaluating information from variety of sources, as well as to have good critical thinking, problemsolving and interpersonal communication skills. Powerful learning of this nature demands teachers who are well prepared and well suited to the needs of the learners (Darling-Hammond, 2006). The quality of the instruction and teacher started to be considered as key factors for student performance, which in turn directed attention to teacher education. In many countries teacher education programs have been redesigned based on the contemporary theories and good teaching practices. In line with these changes, in Turkey an educational reform movement started in 1999 and as part of this movement all teacher education programs, including teaching English as a foreign language program, were restructured. The basic drive of this reform was to bring uniformity and standardization to teacher training and certification (Seferoğlu, 2006). However, we still have little information on the teaching competency level of the graduates and how they vision themselves as teachers of future.

\footnotetext{
1 Assistant Prof. Dr., Yıldız Technical University, Faculty of Education, Foreign Languages Education Department, gulruyuksel2002@gmail.com
} 
Yüksel, H. G. (2014). Teachers of the future: Perceived teaching competences and visions of pre-service English language teachers. International Journal of Human Sciences, 11(2), 27-39. doi: 10.14687/ijhs.v11i2.2920

Gaining insights about how student teachers project themselves as teachers of 21 st century and how they envision themselves in terms of teaching competences would give invaluable information to both teacher educators and policy makers who are responsible for shaping and reshaping policies and practices accordingly. If we expect to take accurate and relevant curriculum restructuring decisions that will result in desirable changes within student teachers, and to help them acquire the knowledge, skills and dispositions that will allow them to succeed, it is important to discover their beliefs and conceptions about teacher-student roles, teaching and learning processes.

\section{Teaching competences}

In the late 1980s and early 1990s two trends influenced educational policies worldwide. The first is the appearance of global economy and the second is the expansion of the Internet worldwide network access. The outcomes of these trends varied on two levels. On the macro-structure the increased global competition forced several countries respond the change by adopting neo-liberal economic policies and by directing their attention to reforming their educational systems, which will enable them to become more competitive actors (Güven, 2008). On the microstructure as the boundaries opened up and disappeared with globalization and information technologies, the way people communicate, work and learn also changed. With these drivers considerable international attention has been focused on the quality of teaching. Various reports worldwide pointed out that qualified teachers are the keys to raising quality and status of workforce, hence sustaining growth (see reports for example, OECD 2005; 2009). This submission has also found evidence in research, and teacher quality has been shown to be the most important in-school factor in student achievement (e.g., Rowan et al., 2002; Sanders et al., 1997). Consequently, the educators, scholars, and policymakers have been compelled to reconsider teacher education.

With the re-emergence of teacher education in policy agendas, countries worldwide have taken steps aiming at implementing professional standards, strengthening teacher education and certification requirements (Darling-Hammond, 2010). The keystone question raised was the core knowledge and skills that a teacher was required to have. Drawing on research in educational sciences and studies of classroom practices, several countries have published guidelines to define what high quality teaching is (e.g. National Board for Professional Teaching Standards in the U.S or Teachers' Standards in the U.K). The main intent was to revise and strengthen the professional profile of effective $21^{\text {st }}$ century teachers. While the standards vary in content from one country to another, the underlying principle is congruent: to specify key professional knowledge, values and attitudes, in other words, teacher competences (European Commission, 2013). The minimum requirements agreed upon are the content knowledge, pedagogical knowledge and pedagogical content knowledge.

In Turkey, particularly as part of the integration process to the European Union, the Turkish Ministry of National Education (MoNE) initiated a project to restructure education in 1999. Within the scope of this project, national teacher standards have been finalized and endorsed in 2006. The generic teaching competencies have been collected under six basic domains as "Personal and Professional Values-Professional Development", "Knowing the Student", "Learning and Teaching Process", "Monitoring and Evaluation of Learning and Development", "School-Family and Society Relationships", and "Knowledge of Curriculum and Content", which were further divided into subcompetencies and for each sub-competence performance indicators were defined (MoNE, 2006). In response to these changes, the Higher Education Council (HEC), the sole official body responsible from higher education, has embarked on organizational and curriculum changes in order to strengthen teacher education (Kirkgöz, 2007). With the curricular reform the HEC set out to resolve the structural and conceptual fragmentation in all teacher education programs (for further information see, Grossman et al., 2010; Akşit, 2007). Thus, as part of this reform in order to ensure quality and to provide a solid foundation for student teachers a competency-based model 
Yüksel, H. G. (2014). Teachers of the future: Perceived teaching competences and visions of pre-service English language teachers. International Journal of Human Sciences, 11(2), 27-39. doi: 10.14687/ijhs.v11i2.2920

was adopted. Accordingly, HEC set the following four competence areas and the performance standards expected from the graduates of education (YÖK, 1999):

1. Content and pedagogic knowledge

2. Planning, teaching, classroom management and communication

3. Monitoring, assessment and reporting

4. Other professional requirements (reflectivity, flexibility, objectivity)

With this model in order to help future teachers develop the knowledge, skills, and practices for teaching English as a foreign language (EFL) pre-service teachers are given opportunities to amalgamate pedagogy and subject knowledge through practice in real classroom settings. In other words, they are given chance to "learn to practice in practice" (Darling-Hammond, 2010 p. 40). This clinical practice during initial teacher education is suggested to provide prospective teachers "develop an image of what teaching involves and requires" (Hammerness, Darling-Hammond, \& Bransford, 2005, p. 398). At the end of this practicum period, student teachers are evaluated via using a grid prepared by HEC designed according to the teaching competences performance indicators.

In the Turkish context research investigating pre-service EFL teachers' perceptions on their teaching competencies is few in number. In a study conducted by Şall-Çopur (2008) it was found that the EFL graduates perceived themselves competent in most of HEC's competence areas, while they need improvement for competencies of language knowledge, spoken use of English, classroom management, assessment and instruction. Similarly, Kömür (2010) investigated the relationship between pre-service teachers' teaching knowledge and self-rating of competencies and their practicum experience and found that the ELF students felt sufficiently equipped in the teacher competency. In a recent study, Kizilaslan (2011) explored senior EFL student teachers' competencies regarding teaching of the four language skills and she found a misfit between the competencies required by the Ministry and the competencies exhibited by the student teachers.

\section{Pre-service teachers' visions}

Learning to teach, likened to a journey to becoming a teacher (Freese, 2006), is a complex process throughout which necessary teaching knowledge and skills gained and conceptions about the nature of learning and teaching are formed (Collins, Selinger, \& Pratt, 2001). Many student teachers, enrolled in their programs with already existing beliefs, dispositions and attitudes, are de-educated and enculturated into teaching profession. Throughout teacher training, in addition to gaining knowledge and skills, student teachers also develop an identity as a teacher (Hammerness, et al., 2005). Hammerness, Darling-Hammond and Bransford (2005) consider teacher identity as critically important arguing that the identities teachers develop shape their dispositions, their effort in professional development and their understanding of teacher roles. Teacher training programs, by emphasizing various aspects of teaching and learning, act as agents for the development of teacher identities. Hammerness $(2003,2009)$ argues that programs designed with a clearly articulated shared vision reinforce images of good teaching, which in turn help teacher candidates develop self-images - visions.

Vision, though rooted in beliefs, is different from beliefs since it is a teacher's personal commitment to inspire children (Fairbanks, et al., 2010). Different scholars define vision in various ways. For example, while Shulman and Shulman (2004) describe it as images of particular learning activities that represent how the teacher will teach, Duffy (2002) defines it as "a personal stance on teaching that rises from deep within the inner teacher and fuels independent thinking" (p. 334); and Hammerness (2008) considers it as the teacher's image of ideal classroom practice — what the 
Yüksel, H. G. (2014). Teachers of the future: Perceived teaching competences and visions of pre-service English language teachers. International Journal of Human Sciences, 11(2), 27-39. doi: 10.14687/ijhs.v11i2.2920

classroom environment will be. These self-images mediate between thought and action (FiemanNemser \& Floden, 1984) and guide their teaching classroom practices (Shulman \& Shulman, 2004). Fairbanks and colleagues (2010) further claim that "vision may take teachers beyond knowledge, instilling in them a commitment to inspire students to be something more than just academically competent" (p. 164). Thus, Hammerness (2003) suggests studying teachers' vision in order to better understand and appreciate the decisions they make in their classrooms.

As for the pre-service teachers, examining vision may provide teacher educators information on the deficits of the curriculum, as well as help us better understand student teachers' strengths and weaknesses. According to Hammerness (2003), it may provide a means for teacher educators in three ways: 1) to validate and build on teachers' hopes and dreams, 2) to help new teachers "plumb the depths" of their beliefs and goals and 3) to assist new teachers to understand and deal with the gap between their hopes and their practice (p.52). Compared to the rising interest in teachers' vision in the Western cultures, research in Turkey concerning pre-service teachers' vision in general and pre-service language teachers' vision in particular is scarce. To our knowledge there is a single study in EFL context conducted by Tercanloglu (2001), examining pre-service teachers' views of themselves as readers and future reading teachers. With respect to self-perceptions as future teachers of reading in an EFL, she reported that the pre-service teachers themselves were not very motivated to teach reading. Despite the emphasis on language teacher competences and teacher quality, we still know very little about pre-service EFL teachers' visions and future projections, as well as their perceived level of teaching competence.

The goal of this study was to investigate the perceptions of pre-service EFL teachers regarding their level of teaching competences, and their visions. Thus, the central research questions of this study are:

1. To what extent do pre-service teachers perceive themselves competent as EFL teachers?

2. How do they project themselves as future EFL teachers?

\section{Method and Material}

Since the research aimed at investigating the pre-service teachers' (henceforth, PTs) perceived level of teaching competences together with their future projections, the study employed a convergent parallel mixed-method design in which both quantitative and qualitative data were collected independently and then merged. Data was collected following the last student teaching at the end of the spring semester.

\section{Participants}

In the study the participants were full-time undergraduates of TEFL (Teaching English as a Foreign Language) program at a Turkish state university. The data was collected in 2012-2013 academic year. The program is a 4-year pre-service TEFL teacher-training program, with a yearly intake of 65 students. 40 pre-service EFL teachers (12 male, 28 female), aged 20-21 participated in the study. All of them were native speakers of Turkish.

\section{Data sources}

The quantitative data was collected utilizing Teaching Competences Self-Assessment Tool. The tool was originally developed by Fer (2007) to be used by the observing supervisor in order to assess teaching competences of PTs' student teaching. Originally Fer (2007) developed the tool by using the practicum assessment grid which is filled in by the observing supervisor. The researcher adapted the tool by re-writing the statements as "can-do" statements. The tool is a 38-item likert scale self-assessment asking PTs to evaluate their perceived capacities in the following domains: content knowledge, pedagogical content knowledge, instructional strategies, classroom 
Yüksel, H. G. (2014). Teachers of the future: Perceived teaching competences and visions of pre-service English language teachers. International Journal of Human Sciences, 11(2), 27-39. doi: 10.14687/ijhs.v11i2.2920

management and student engagement. The participants responded each item on a 4-point scale ranging from (4) excellent to (1) poor. Sample statements are given below:

- I can identify misunderstandings and misconceptions in student learning (pedagogical content knowledge)

- I can choose the evaluation and assessment technique best suit my students (instructional strategies)

- I can manage disruptive student behavior (classroom management)

The tool was administered after student teaching before supervisor-student teacher seminar. The Cronbach alpha value measured by the researcher was 0.80 .

The qualitative data was collected through teaching philosophy papers which the participants were supposed to write as a final task at the end of student teaching. This study is not a design experiment in which an intervention is designed and implemented (Collins, Joseph, \& Bielaczyc, 2004), but rather, is descriptive in nature aiming at exploring PTs' personal projections at the end of teacher training. Therefore, the teaching philosophy was a written reflection task they were supposed to include in their student teaching dossiers. The software MAXQDA was used to assist in organizing the data emerging from the papers. The data was analyzed using content analysis method (Miles \& Huberman, 1994). After reading student papers, the texts were divided into minimum meaning units and each unit was coded. When the initial coding of data was completed, codes were grouped into categories and themes. In the process of data analysis, two research team members crosschecked the coding of responses and the categorizations, and refined the set of codes in the light of insights generated from reading and coding the data. Consensus was achieved upon discussions on differences in coding and categorizing the themes. The reliability of the data analysis was enhanced through this crosschecking process (Cohen, Manion \& Morrison, 2000).

\section{Findings}

Findings presented below are divided into two parts; findings in terms PTs' self-assessment of teaching competences and findings in terms of their future projections.

\section{Pre-service teachers' teaching competences self-assessment}

The quantitative data, collected via Teaching Competences Self-Assessment Tool, was analyzed in order to examine the student teachers' perceived strengths and weaknesses in five teaching competency domains. The overall mean score for the teaching competences self-assessment tool was found 2,6 with a standard deviation of 0,06 . The overall mean indicated a medium level of selfefficacy. The results showed that they felt themselves more competent in content knowledge $(m=2,73)$, student engagement $(m=2,69)$ and pedagogical content knowledge $(m=2,6)$. However, our students perceived themselves to be less competent in the domains of instructional strategies $(\mathrm{m}=2,55)$ and classroom management $(\mathrm{m}=2,54)$ (see figure 1$)$.

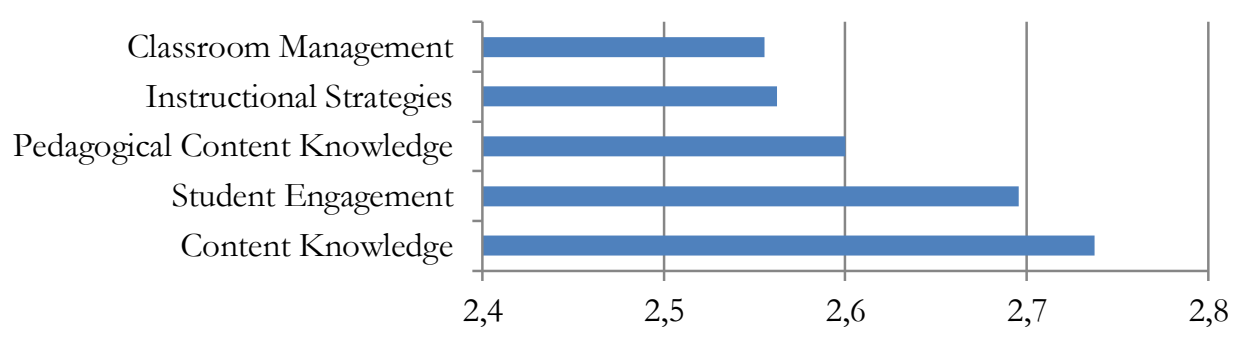

Figure 1: Student teachers' self-assessment results in six competence domains 
Yüksel, H. G. (2014). Teachers of the future: Perceived teaching competences and visions of pre-service English language teachers. International Journal of Human Sciences, 11(2), 27-39. doi: 10.14687/ijhs.v11i2.2920

The small standard deviation measured in the analysis shows that our data points are close to the overall mean, which indicated that the responses of the participants were fairly uniform, and there was a general consensus among the sample. In other words, the PTs participated in the study had fairly uniformed perceptions regarding their teaching competences.

When analyzing each of these six domains in depth, the statement with mean one standard deviation lower than the overall mean score was classified as an area which needs improvement. The areas of practice in need of improvement were working with diverse population $(\mathrm{m}=2,17)$, time management $(\mathrm{m}=2,33)$, monitoring student progress $(\mathrm{m}=2,35)$, preventing disruptive behaviour $(\mathrm{m}=2,41)$, connected learning $(\mathrm{m}=2,46)$, giving homework and assignments $(\mathrm{m}=2,48)$, motivating learner $(\mathrm{m}=2,48)$, assessing learning $(\mathrm{m}=2,48)$ and error correction and giving feedback $(\mathrm{m}=2,53)$ (see figure 2$)$.

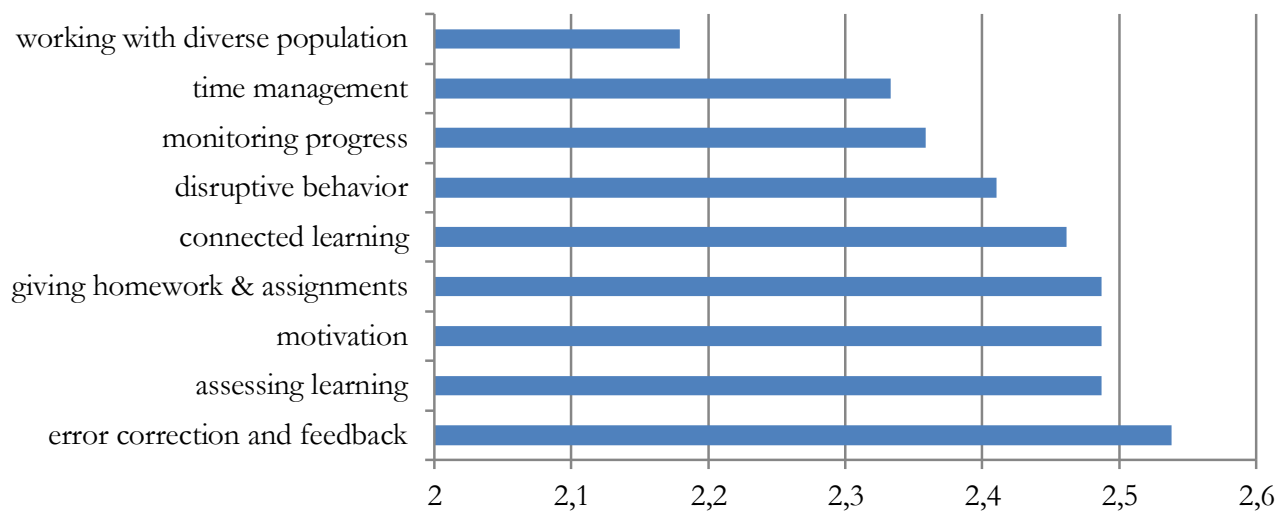

Figure 2: Areas of practice in need of improvement

\section{Findings in terms of pre-service teachers' visions}

The themes addressed by most participants were coded under the following six categories: 1) becoming a teacher, 2) teaching styles and teacher role, 3) expected learning outcomes, 4) methodology 5) materials and 6) learning environment. The themes, definitions and percentages were presented in Table 1. The findings will be presented with direct quotations from the participants. The names initials were used in the quotations.

Table 1.

Themes, definitions, frequencies and percentages

\begin{tabular}{|c|c|c|c|}
\hline Themes/codes & Definition & f & $\%$ \\
\hline \multicolumn{4}{|l|}{ Becoming a teacher } \\
\hline professional development & openness to innovations, following the new trends in education & 19 & 48 \\
\hline teacher training & gains from undergraduate program, practicum, student teaching & 8 & 20 \\
\hline past experience & student teacher's experience as a high school student & 11 & 28 \\
\hline technological knowledge & knowledge about technological language teaching tools & 1 & 3 \\
\hline pedagogical knowledge & $\begin{array}{l}\text { knowledge about the processes and practices or methods of language teaching } \\
\text { and learning }\end{array}$ & 4 & 10 \\
\hline content knowledge & subject-matter knowledge & 3 & 8 \\
\hline \multicolumn{4}{|l|}{ Teaching styles \&o teacher roles } \\
\hline delegator & $\begin{array}{l}\text { teacher places much control and responsibility for learning on individuals or } \\
\text { groups of students }\end{array}$ & 4 & 10 \\
\hline demonstrator & $\begin{array}{l}\text { teacher models what is expected (skills and processes) and then acts as a coach to } \\
\text { assist the students in applying the knowledge. }\end{array}$ & 2 & 5 \\
\hline leader & teacher serves on a committee, supporting school initiatives & 1 & 3 \\
\hline presenter & teacher as a source of information & 4 & 10 \\
\hline mentor & teacher serves as a role model & 7 & 18 \\
\hline facilitator & $\begin{array}{l}\text { teacher focuses on activities and places responsibility on the students to take } \\
\text { initiative to achieve results for the various tasks. }\end{array}$ & 10 & 25 \\
\hline guide & teacher acts as a coach or guide to assist the students in applying the knowledge & 10 & 25 \\
\hline
\end{tabular}


Yüksel, H. G. (2014). Teachers of the future: Perceived teaching competences and visions of pre-service English language teachers. International Journal of Human Sciences, 11(2), 27-39. doi: 10.14687/ijhs.v11i2.2920

\begin{tabular}{|c|c|c|c|}
\hline \multicolumn{4}{|l|}{ Expected learning outcomes } \\
\hline $\begin{array}{l}\text { life-long learning \& learner } \\
\text { autonomy }\end{array}$ & learning to learn, learner autonomy & 12 & 30 \\
\hline communicatively competent & good communication skills & 5 & 13 \\
\hline critical thinking \& creativity & problem-solving skills & 13 & 33 \\
\hline active participant & active participation in class activities & 10 & 25 \\
\hline \multicolumn{4}{|l|}{ Teaching methodology } \\
\hline student-centered & focuses attention on what the student is learning and active student participation & 23 & 58 \\
\hline incorporating learner diversity & methodological and pedagogical principles signaling learner diversity & 23 & 58 \\
\hline discovery learning & inquiry-based instruction & 15 & 38 \\
\hline activating prior knowledge & utilizing prior knowledge in teaching & 1 & 3 \\
\hline cross-curricular teaching & taking other subject areas into consideration while planning & 1 & 3 \\
\hline authentic teaching & utilizing real-life situations, issues and tasks while teaching & 20 & 50 \\
\hline \multicolumn{4}{|l|}{ Instructional design principles } \\
\hline learner needs & paying attention to learner variables & 11 & 28 \\
\hline authentic resources & utilizing real-life objects and materials & 7 & 18 \\
\hline technology as a tool & seeing technology as an important educational tool & 10 & 25 \\
\hline \multicolumn{4}{|l|}{ Learning environment characteristics } \\
\hline stress-free \& non-threatening & classrooms in which learning is fun & 24 & 60 \\
\hline democratic classroom & equal learning opportunities & 7 & 18 \\
\hline
\end{tabular}

\section{Becoming a teacher}

Under the theme of becoming a teacher the most frequently repeated code was "professional development" which is related to the need of being up-to-date and keeping up with the changes and innovations while practicing as a teacher. When we consider that our participants were preservice teachers, the frequency of this code was quite promising.

As a teacher of future, I know that I should keep myself educated through constant reading and learning about new ways of teaching English. But I am well aware of the fact that reading is not enough, therefore I would like to be more involved in educational activities, attend educational talks and participate in forums or conferences to further expand my knowledge [EA].

This can be interpreted as an indication of enthusiasm towards teaching profession and being aware of the importance of following developments in teaching and learning. During their journey to becoming a teacher, nineteen participants mentioned their gains from their undergraduate program and the influence of practicum experience. One PT, for example, described practicum as "an invaluable experience" increasing her teaching efficacy. In addition, eleven out of forty mentioned their past experiences as a high school student, and how those experiences influenced shaping their idea of good teacher. For example, one of the PTs reported the positive influence of her high school English teacher by saying:

When I was at high school, my English teacher, taught us English by using inductive methodology. His lessons were always fun and I learned much in this way. And now, I remember my experiences as a learner and want to be a teacher like him [HA].

\section{Teaching styles and teacher roles}

In their teaching philosophy essays the most frequently mentioned teacher roles were being a role model, facilitator and guide. The teaching styles preferred by the majority of the PTs were teacher as facilitator, teacher as guide and teacher as delegator.

I will always try to understand my learners and be as supportive as possible. I know that I will encounter with difficulties and everything will not be as ideal as I hope. But I believe I can overcome these difficulties by experience. [YB]

I believe in order to establish a good learning environment; a teacher should act as a guide and direct the kids' curiosity towards learning. I hope to be a guide; provide access to 
Yüksel, H. G. (2014). Teachers of the future: Perceived teaching competences and visions of pre-service English language teachers. International Journal of Human Sciences, 11(2), 27-39. doi: 10.14687/ijhs.v1112.2920

information rather than acting as the primary source of information. I am well aware of the fact that I need to create opportunities for my students to discover and practice their skills in authentic situations. [CÖ]

I believe in focusing on individual needs, and involving students in the process of their own learning. And I think that individual differences need to be recognized, respected, and even celebrated in language classrooms. [BI]

Although they were few in number, there were PTs who preferred more teacher-centred styles. For example, FA defines teaching as "transferring knowledge to others" and EC defines teacher as "the source of knowledge". Although these participants did not describe themselves as formal authority, still they considered themselves as presenters and source of information.

\section{Expected learning outcomes}

As for the expected learning outcomes, we could detect the following four recurring codes: 1) lifelong learning and learner autonomy, 2) communicatively competent, 3) critical thinking and creativity and 4) active participant. More than half of the PTs mentioned active student participation and critical thinking as their main expected learning outcomes.

I believe that by creating a student-centred learning, my students will be able to take the responsibility of their own learning. [MU]

My philosophy is comprised of four main components. First, I believe in fostering independent, critical thinking, which ignites the spark of curiosity. Second, in order to keep the spark alive, which furthers knowledge and promotes innovation, we must facilitate the acquisition of independent, life-long learning skills. Third, by preparing students to be respectful, equitable participants of society, we can utilize innovation and advanced knowledge. Finally, I believe in teaching effective communication. In my effort to achieve these objectives, it is my sincere hope is that my students would leave my class not with information about English, but as individuals who are communicatively competent in English. [EA]

When we consider these codes in relation to teaching styles and teacher roles, we see that the expected learning outcomes are actually in harmony with the preferred teaching styles.

\section{Teaching methodology}

Regarding the conceptions of teaching methodology student-centred teaching caring for motivation and learner diversity appeared to be the basic teaching methodology. Incorporating learner diversity in instruction and discovery learning were the most frequently repeated methodological principles. Half of the student teachers also emphasized making connections to real-life situations and problems, which was coded as "authentic teaching", as a guiding principle in activity design and instruction. These frequently recurring codes might actually be considered under an umbrella term: constructivist teaching.

As a teacher candidate, my first aim is to make sure that my students do not see English just as a lesson but as a skill that will contribute to their lives in many ways. This is possible only by giving them the freedom to think and discover. To ensure this, I plan to use inductive teaching method in my classes. Moreover, I also appreciate that each individual is unique; therefore I will take their ideas, opinions, criticisms and suggestions into consideration. These are my key principles for teaching. [YS]

I believe that giving importance to contextualized learning and creating opportunities for students to use and practice the language is of great significance. [ZC]

\section{Instructional design principles}


Yüksel, H. G. (2014). Teachers of the future: Perceived teaching competences and visions of pre-service English language teachers. International Journal of Human Sciences, 11(2), 27-39. doi: 10.14687/ijhs.v11i2.2920

Seven PTs out of forty expressed the idea that being "authentic" should be the basic quality of effective classroom materials. Additionally, learner variables like interest, age and needs were sated as important points to be considered in syllabus design. Although only one half of the PTs mentioned about the nature of materials they will utilize in their future careers, it was promising to see that they recognized technology as a teaching tool.

She/he [teacher] has to plan according to the students' level, learning pace and needs. [SM]

Teaching materials and methods to be used in a language classroom should be interactive, interesting, entertaining and more importantly authentic. [YE]

I like to utilize technological tools in my lessons, because I believe that electronic materials and software will help me actively involve my students into the lesson. [YS]

\section{Learning environment characteristics}

There was a consensus among PTs on the idea that classroom environment influences learning. The basic qualities they mentioned to describe language classroom that foster learning were comfortable, non-threatening, stress-free and democratic.

In English lessons I think developing students' communication skill is the ultimate goal. I want to create a stress free environment for my students, so that they can speak, learn and communicate without anxiety. [ZO]

In my opinion, a caring and safe classroom in which pupils are given equal rights and responsibilities fosters learning. The children can become responsible members of the classroom community by using strategies such as class meetings, positive discipline, and democratic principles. I believe that I can give them the tools to become successful in life, to develop self-confidence, and to love others. [B]

\section{Discussion}

The findings from the teaching competence self-assessment indicated that our PTs' perception related to various teaching competencies were uniform. The overall average indicated that they felt themselves competent enough in teaching. The strongest competency domain was contentknowledge; however, the weakest competency domain was the classroom management. This result showed that they needed further help in classroom management. Actually, classroom management appears to be one of the basic issues of pre-service and novice EFL teachers. For example, in her study with novice ESL teachers Numrich (1996) found that establishing good classroom management routine was the most initial concern of the subjects. One way of helping student teachers could be through creating more opportunities to work with learners.

When we consider the specific areas that need improvement, "working with diverse population" appeared to be the most urgent area to be catered. Particularly in the 21 st century, due to the high mobility, classroom populations are becoming highly diverse. Learners are coming from different social, economic and ethnic backgrounds with a variety of educational backgrounds and learning styles. Since the composition of the class directly influence teaching and learning, we should consider making necessary changes in our course contents and teach pre-service teachers how to work with diverse populations. Some of other areas needing improvement, such as managing time, keeping motivation alive and managing disruptive behaviour are related to classroom management which are closely related to the efficiency of clinical practice. With respect to student teachers' competency level and the areas they need support our findings are in line with the studies conducted in Turkey (Seferoğlu, 2006; Şall-Copur, 2008).

From the findings of the qualitative data we can infer that our participants favour student-centred instructional strategies which foreground learning styles, needs and pace of the learner, which foster 
Yüksel, H. G. (2014). Teachers of the future: Perceived teaching competences and visions of pre-service English language teachers. International Journal of Human Sciences, 11(2), 27-39. doi: 10.14687/ijhs.v11i2.2920

learner autonomy and life-long learning over teacher-centred strategies. They prioritize authentic teaching as a guiding principle in activity design and instruction. They emphasized the importance of comfortable, non-threatening, stress-free and democratic classroom atmosphere in students' learning. All of these could be interpreted as a signal that our participants will possibly adopt a constructivist approach to teaching. However, this tendency should be strengthened through more clinical experiences. As the statements of our student teachers confirmed, while becoming a teacher not only the theoretical information gained during the graduate programs, but also the practicum and student teaching experiences had great influence on their pedagogical formation.

One important theme that we expected to find in our participants' papers was the role of technology in teaching. There were only a few student teachers who emphasized the role of technology in teaching English as a foreign language and technology is an important instructional tool. This might be interpreted in two different ways: either technology did not have a place in our PTs' previous experiences as students for this reason they do not consider technological tools as having value in instruction, or rather they do not have enough pedagogical and technological knowledge to turn it into a regular instructional tool. Depending on my observations, I can say that the first is not the case as they use technology every day in their lives, but they are not good at using it as a tool in instructional settings. One reason of this is that although this new generation of undergraduates is technology proficient, in the current TEFL curriculum we are still teaching them about ICT and its tools rather than how to make use of these tools in classroom settings. The other reason is that we as teacher educators are not using ICT tools as part of our teaching practices that they could model.

\section{Limitations}

It is important to note here that not only is this a small scale study, but the findings are limited by the self-assessments and teaching philosophy papers of 40 pre-service teachers. Due to the limited sample size and the nature of data being self-reports, one needs to be cautious about the interpretation of the results. Furthermore, participants' future teaching projections were identified from their teaching philosophies written as a part of course requirement. Therefore, the teaching philosophies described in this study are pre-service teachers' espoused beliefs that may be normative in nature i.e., written to satisfy the reader or ideal that may not be enacted due to constraints. Hence, caution needs to be taken in understanding the findings gathered from the qualitative data. It should also be noted that although the written responses add to the accuracy of the data, exploring interesting and unexpected ideas or themes raised by the participants that might have been explored in face-to-face interviews were not available for the analysis. Thus, in future research studies inviting students for interviews over teaching competences would be of value.

\section{Conclusion and implications}

The results of the study give way to certain implications for community of teachers and teacher trainers. Schools that have become genuine learning organizations must be enabled to work in teams with smart networks; and to establish new learning cultures, teaching norms, and learning standards. Teachers must be inducted into new learning communities and initiatives and rewarded for student growth. Ensuring that every child has the opportunity to successfully participate in a knowledge-based, global workforce is a demanding challenge that requires the transformation of teacher preparation programs.

More opportunities should be created for student teachers to strengthen their competencies through experiences. The most efficient and effective way of helping them gain skills and competences is to create clinical experience opportunities to work with learners for longer periods. 
Yüksel, H. G. (2014). Teachers of the future: Perceived teaching competences and visions of pre-service English language teachers. International Journal of Human Sciences, 11(2), 27-39. doi: 10.14687/ijhs.v11i2.2920

Clinical experience will help them contextualize their learning and understand how children learn and behave. Through practice in real classroom settings their confidence, understanding and ability of teaching will increase. With the current curriculum our student teachers try to gain experience only through $6 \mathrm{~h} / \mathrm{w}$ student teaching for 10 weeks period. We should consider creating new ways and opportunities for pre-service teachers to work with children well before senior year. As stated by Darlington-Hammond (2006) if we want teachers to "understand deeply a wide array of things about learning, social and cultural contexts, and teaching and be able to enact these understandings in complex classrooms serving increasingly diverse students" we need to engage ever more closely with schools and can seek for partnerships with local government bodies, businesses and NGOs working on child education.

In order to facilitate 21 st century learning which calls for an immediate integration and implementation of ICT and to respond the demands, three enablers need to work together: resources, skills and curriculum. The Turkish MoNE has taken several measures regarding resources, and classrooms have been equipped with computers, laptops and smart boards. A classroom fully equipped with the tools and materials is more likely to achieve success than is a poorly resourced one. But providing resources is the easiest task to carry out. The key to integration is the classroom teacher's skills. Skills fall into two categories as technical and pedagogical. With skill and pedagogy a classroom teacher can manage limited resources, structure lessons to enable all students to have access to resources and may overcome limited resources. However, this is possible only through giving appropriate training and education to the teachers of future. The curriculum must change to reflect the paradigm shift we are experiencing.

We should redesign our pre-service programs to equip future teachers for their role in preparing students to live in a changing world. In order to strengthen teacher preparation more subject matter preparation, more intensive coursework on content pedagogy and more systematic and connected clinical experience is needed. Our students' recognition of the role of technology, signals us that the integration of information and communication technologies in the pre-service teaching and learning process should be reconsidered. Currently, our teacher education program includes a technology module. However, the focus is typically on technology skills and applications rather than the integration of technology across the curriculum. Now it is time to move from "learning about and with ICT" to "learning through ICT" phase (Pelgrum \& Law, 2003) and integrate ICT as an essential tool in the curriculum. In order to adequately prepare future teachers, teacher educators need professional development in technology skills and applications, as well as in new pedagogical methods of incorporating technology into classrooms.

\section{References}

Aksit, N. (2007). Educational reform in Turkey, International Journal of Educational Development, 27, 129-137. doi: 10.1016/j.ijedudev.2006.07.011

Cabaroglu, N., \& J. Roberts. (2000). Development in student teachers' pre-existing beliefs during a 1-year PGCE programme. System, 28(3), 387-402. doi: 10.1016/S0346-251X(00)00019-1

Cohen, L., Manion, L \& Morrison, K. (2000). Research Methods in Education (5th ed). London: Routledge.

Collins, A., Joseph, D. \& Bielaczyc, K. (2004). Design research: Theoretical and methodological issues. Journal of the Learning Sciences, 13(1), 15-42. doi:10.1207/s15327809jls1301_2

Collins, J.B., Selinger, S.J. \& Pratt, D.D. (2003). How do perspectives on teaching vary across disciplinary majors for students enrolled in teacher preparation? Retrieved from http://teachingperspectives.com/PDF/howdoteachers.pdf

Darling-Hammond, L. (2000). How teacher education matters. Journal of Teacher Education, 51(3), 166-173. doi: 10.1177/0022487100051003002 
Yüksel, H. G. (2014). Teachers of the future: Perceived teaching competences and visions of pre-service English language teachers. International Journal of Human Sciences, 11(2), 27-39. doi: 10.14687/ijhs.v11i2.2920

. (2006). Constructing 21st-Century teacher education. Journal of Teacher Education, 57(3), 300-314. doi: 10.1177/0022487105285962

. (2010). Teacher education and the American future. Journal of Teacher Education, 61(12), 35-47. doi: $10.1177 / 0022487109348024$

Duffy, G. G. (2002). Visioning and the development of outstanding teachers. Literacy Research and Instruction, 41(4), 331-343. doi:10.1080/19388070209558375.

European Commission. (2013). Supporting teacher competence development. Retrieved from http://ec.europa.eu/education/policy/school/doc/teachercomp en.pdf

Fairbanks, C., Duffy, G. G., Faircloth, B., He, Y., Levin, B. B., Rohr, J., \& Stein, C. (2010). Beyond knowledge: Exploring why some teachers are more thoughtfully adaptive than others. Journal of Teacher Education, 61, 161-171. doi: 10.1177/0022487109347874

Fer, S. (2007). Matematik, fizik ve kimya öğretmen adaylarının yeterlilikleri üzerine bir inceleme, [A study on the competences of pre-service mathematics, physics and chemistry teachers] Paper presented at 16th National Congress of Educational Sciences, Tokat, September 57.

Feiman-Nemser, S., \& Floden, R. E. (1984). The cultures of teaching. Occasional Paper No. 74. ERIC Number: ED251423

Freese, A.R. (2006). Reframing one's teaching: Discovering our teacher selves through reflection and inquiry, Teaching and Teacher Education, 22, 100-119. doi:10.1016/j.tate.2005.07.003

Grossman, G. M., Sands, M. K., \& Brittingham, B. (2010). Teacher education accreditation in Turkey: The creation of a culture of quality. International Journal of Educational Development, 30(1), 102-109. doi:10.1016/j.ijedudev.2009.08.003

Güven, I. (2008). Teacher education reform and international globalization hegemony: issues and challenges in Turkish teacher education. International Journal of Human Social Sciences, 3(1), 817. Retrieved from: http://www.waset.org/publications/11625

Hammerness, K. (2003). Learning to hope, or hoping to learn?: the role of vision in the early professional lives of teachers. Journal of Teacher Education, 54(1), 43-56. doi: $10.1177 / 0022487102238657$

- . (2008). "If You Don't Know Where You Are Going, Any Path Will Do": The Role of Teachers' Visions in Teachers' Career Paths. The New Educator, 4(1), 1-22. doi: $10.1080 / 15476880701829184$

-- . (2009). The Relationship between Teacher Education Program Visions and Teacher's Visions: An examination of three programs. Retrieved from http://www.brandeis.edu/mandel/pdfs/Hammerness Relationship 0909.pdf

Hammerness, K., Darling-Hammond, L., \& Bransford, J. (2005). How teachers learn and develop. In L. Darling-Hammond \& J. Bransford, (Eds.), Preparing teachers for a changing world: What teachers should learn and be able to do, pp. 358 - 389. San Francisco, CA: Wiley \& Sons.

Kagan, D. M. (1992). Implication of research on teacher belief. Educational psychologist, 27(1), 6590.

Kurkgöz, Y. (2008). A case study of teachers' implementation of curriculum innovation in English language teaching in Turkish primary education. Teaching and Teacher Education, 24(7), 1859-1875. doi: 10.1016/j.tate.2008.02.007

Kizilaslan, I. (2011). ELT student teachers' competence for teaching language skills: a qualitative exploration. International Journal of Social Sciences and Humanity Studies, 3(1), 161-169.

Kömür, Ş. (2010). Teaching knowledge and teacher competencies: a case study of Turkish preservice English teachers. Teaching Education, 21(3), 279-296. doi:10.1080/10476210.2010.498579

Miles, M. \& Huberman, A. M. (1994). Qualitative Data Analysis. Thousand Oaks, CA: Sage.

MoNE. (2006). Generic Teaching Competencies. Ankara. Retrieved from: http://otmg.meb.gov.tr/belgeler/otmg/Generic Teacher Competencies.pdf 
Yüksel, H. G. (2014). Teachers of the future: Perceived teaching competences and visions of pre-service English language teachers. International Journal of Human Sciences, 11(2), 27-39. doi: 10.14687/ijhs.v11i2.2920

Numrich, C. (1996). On becoming a language teacher: Insights from diary studies. TESOL Quarterly, 30(1), 131-153.

OECD. (2005). Teachers Matter: Attracting, Developing and Retaining Effective Teachers. Paris: Organisation for Economic Co-operation and Development. Retrieved from http://www.oecd.org/edu/school/48627229.pdf

OECD. (2009). Education at a Glance. OECD Indicators. OECD Publishing. doi: 10.1787/eag-2009en

Pajares, M. F. (1992). Teachers' beliefs and educational research: Cleaning up a messy construct. Review of Educational Research, 62(3), 307-332. doi: 10.3102/00346543062003307

Peacock, M. (2001). Pre-service ESL teachers' beliefs about second language learning: A longitudinal study. System, 29(2), 177-195. doi: 10.1016/S0346-251X(01)00010-0

Pelgrum, W. J \& Law, N. (2003). Fundamentals of Education Planning: ICT Education around the world: Trends Problems and Issues, Paris: Unesco, International Institute for Educational Planning.

Rowan, B., Correnti, R., \& Miller, R. J. (2002). What large-scale survey research tells us about teacher effects on student achievement: Insights from the Prospects study of elementary schools. Teachers College Record, 104(8), 1525-1567.

Sanders, W. L., Wright, S. P., \& Horn, S. P. (1997). Teacher and classroom context effects on student achievement: Implications for teacher evaluation. Journal of Personnel Evaluation in Education, 11(1), 57-67.

Seferoğlu, G. (2006). Teacher candidates' reflections on some components of a pre-service English teacher education programme in Turkey. Journal of Education for Teaching, 32(4), 369-378. doi:10.1080/02607470600981953

Shulman, L. S., \& Shulman, J. H. (2004). How and what teachers learn: A shifting perspective. Journal of Curriculum Studies, 36(2), 257-271. doi:10.1080/0022027032000148298

Şalli-Çopur, D. (2008). Teacher effectiveness in initial years of service: A case study on the graduates of METU foreign language education program (Doctoral dissertation, Middle East Technical University).

Tercanlığlu, L., 2001. Pre-service teachers as readers and future teachers of EFL reading. TESLEJ [online], 5(3). Retrieved from: http://www-writing.berkeley.edu/TESL$\mathrm{EJ} / \mathrm{ej} 19 / \mathrm{a} 2 . \mathrm{html}$

YÖK. (1999). Türkiye'de öğretmen eğitiminde standartlar ve akreditasyon. Retrieved from http://tpaker.pamukkale.edu.tr/articles/akreditasyon.pdf 